\title{
The Lake Among the Qu'Appelle Hills
}

\author{
By Mrs. C. A. STEWART, Fairy Hill, Sask.
}

Up among the hills there lies a tiny tarn. This miniature lake is a crescent-shaped basin curving round a grassy slope, which reaches back in rolling tiers to the top of the basin's rim, from where it descends in softly rolling slopes to the valley floor, broken by small wooded ravines and coppices. Here and there huge boulders lie, as if a giant hand had thrown them there at random. The green meadows of the valley floor extend to the valley wall on the south side, where the small hillocks separated by wooded ravines, rise to the prairie.

Above the convex side of the lake the hills rise somewhat abruptly with wooded ravines reaching from the high escarpments almost bare of vegetation so steep are they, and flattening out near the edge of the water.

At either end of the crescent is a round clump of thickly leaved maples, their leaves in the tender green of early summer, interspersed with drooping bunches of near crimson keys, which bend the twigs on which they grow. The whole effect of the red pendicles among the green leaves is one of unusual and striking beauty. Only for a short time can the phenomenon be observed. In a week or ten days the keys will have elongated and become a scarcely lighter green than the leaves.

Just where the inner curve of the crescent begins to bear downward, stands a twin ash tree, its two stems separating above the parent root, and merging again in a perfect oval of long green leaflets which shine with a polished lustre, given to none other of the common trees in the valley.

All around the edge of the water, standing upright in the shallows, are dark green sedges. In the slanting rays of the afternoon sun, these are reflected on the calm surface as "a straight stick bent in a pool." The ash tree is faithfully reproduced in the water, also, and various bushes along the sides appear in a fringe of shadow along the sunward side.

The white and purple sheen on the wing of a mallard drake calls the eye to the farther end of the lake. Upon noting the invader of his solitude he swims swiftly shoreward, leaving a slender $\mathrm{V}$ of white in his wake, on the shadowed water.

.His mate walks warily along the edge, no doubt with fears for her unhatched brood, somewhere in the surrounding bushes.

In the middle reaches of the little lake, where the water lies free of shadows, the snowy shapes of fleecy clouds momentarily lighten the dark blue of the water. So close seem the sky and clouds to their reflections that the eye can gather both in, in one glance.

A Broen Thrasher alights in the ash tree in plain sight, pouring forth a stream of melody, in clear articulation. Just below him, unable to hide his orange waistcoat and black tuxedo, a Baltimore Oriole vigorously scolds the intruder. Among the maples a tiny Yellow Warbler trills ecstatically, repeating over and over his "Kee - lee - wee-chee-chee-cheewee."

Here, if anywhere in this world, where men have created only turmoil and unrest, is Peace.

\section{ROSES ARE RED (Continued)}

One bearded and another, Two unbearded;

Semibearded am I."

The allusion is quite surprising. The five brothers are the five sepals; two have curious appendages - "beards" - on both their edges; two have no such appendages, their edges being quite simple; and one has an appendage on one side only. These peculiarities though pointed out long ago by the monks, you will have to wait until next June to see. I am sure you will be as surprised as I was when I picked up a rose on our next field trip, turned over the flower and examined the exposed edges of the sepals. So until,

"Wenn du eine Rose schaust,

Sag ich lasz sie grüszen."

Translated:

"When you see a rose,

Say I send my greetings." 